\title{
The RELATIONSHIP BETWEEN EMPLOYEE MOTIVATION AND JOB INVOLVEMENT
}

S Govender and SB Parumasur

School of Management Studies, University of KwaZulu-Natal

Accepted March 2010

\begin{abstract}
The study aims to assess the current level of, and relationship between, employee motivation and job involvement among permanent and temporary employees in various departments in a financial institution. This cross-sectional study was undertaken on 145 employees who were drawn by using a simple random sampling technique. Data were collected using the Employee Motivation Questionnaire (Fourie, 1989) and the Job Involvement Questionnaire (Lodahl \& Kejner, 1965) and, was analysed using descriptive and inferential statistics. The results indicate that there are significant intercorrelations among the majority of dimensions and sub-dimensions of employee motivation and job involvement. Recommendations are presented to provide practitioners and managers with guidelines for enhancing employee motivation and job involvement respectively.
\end{abstract}

JEL J28, M12

\section{1 \\ Introduction}

Motivating staff may be a critical factor in ensuring that an organisation thrives and succeeds in an increasingly competitive environment. The rationale is that, as employees become increasingly motivated to perform in their jobs, the likelihood of their becoming job involved increases significantly. Hence, the researchers postulate the existence of a direct relationship between motivation and job involvement. This suggests an important opportunity, that of using the valuable asset of human capital as a means of enhancing success in a turbulent and dynamic corporate environment.

A new employee has a set of needs as well as a set of expectations of the organisation, which change and evolve over time. The extent to which these are satisfied determines the employee's level of motivation to work. Muchinsky (1990) defines motivation as the individual's desire to demonstrate a particular behaviour and to willingly expend effort. Nelson and Quick (2002) propose that motivation may be defined as the process of arousing and sustaining goaldirected behaviour. Odendaal and Roodt (2003) define motivation as the process that accounts for the individual's intensity, direction and persistence in the attainment of a particular goal. Similarly, Greenberg and Baron (2000) and Schultz, Bagraim, Potgieter, Viedge and Werner (2003) define motivation in terms of three things that are relationshiped to behaviour. First, motivation arouses the energy that drives the individual's behaviour, then it directs the individual to choose the correct behaviour for goal attainment, and finally it sustains the individual's behaviour until the goal has been achieved and the need is met. Following these various definitions of motivation, the question arises as to precisely what drives employees to willingly expend effort and arouses them to behave in such a way that the goal is attained and the need is met. Answers to these questions may be found in several theories of motivation that have been developed over the years relating to:

- Content theories, which focus on identifying and understanding employees' needs, that is, questioning and emphasising the needs that cause (or motivate) people to behave 
in certain ways. These theories include Maslow's hierarchy of needs, Herzberg's two-factor theory, Alderfer's ERG theory and McClelland's acquired needs theory. The content theories generally maintain the notion that if an organisation wants to have motivated employees, it must satisfy the needs of its workforce (Lussier, 2000). The content theorists have, in their respective content theories, identified what each considers to be the critical needs in employee motivation, as well as ways in which organisations may fulfil these needs to optimise employee motivation.

- Process theories focus on understanding how individuals are motivated. They include Adams's equity theory, Locke and Latham's goal-setting theory, Vroom's expectancy theory and Skinner's reinforcement theory. Process theories are more complex than content theories in that they attempt to understand why employees have different needs, why their needs change, how and why they attempt to satisfy their needs in different ways, the various mental processes employees go through as they try to understand situations, and how they evaluate need satisfaction (Lussier, 2000).

Mullins (1996, in Gerber, Nel \& van Dyk, 1998) states that employees' motivation to work is comprised of three sub-dimensions, namely, economic rewards, intrinsic satisfaction and social relationships. Economic rewards include pay, benefits, material goods and security, representing an instrumental orientation to work (Pretorius, 2004). Intrinsic satisfaction involves interest in the job itself, the nature of the work, and personal or professional growth and development, and depicts a personal orientation to work. Pretorius (2004) states that the social relationships important to work motivation include friendships, teamwork, status, socialisation, dependency and the desire for affiliation. They symbolise a relationship orientation to work. This aspect is primarily focused on employees' feelings, attitudes and perceptions of supervisors, subordinates and the peers with whom they directly or indirectly interact (Madsen, Miller \& John, 2005).
Variables relating to employee motivation may be grouped in three categories, namely, the work environment, the job and individual characteristics. Three aspects of the work environment impact on motivation:

- The physical work environment, which includes factors like light, temperature, noise, ventilation and rest periods (Lussier, 2000). A work environment characterised by poor lighting, extreme temperatures, high noise levels, poor ventilation and inadequate rest periods results in increased job dissatisfaction and lack of motivation.

- The social work environment, which refers to an employee's interpersonal relationships with close co-workers and immediate supervisors.

- The psychological work environment, which involves how the employee perceives the work itself, as well as the employee's personal job satisfaction (Lussier, 2000). The implication is that the organisation must carefully match the skills, knowledge and abilities of the individual to the best available position, as the employee-job fit affects the psychological work environment.

In terms of job characteristics, the environmental perspective argues that, if employees are provided with the right combination of job circumstances (namely, pay, role clarity, task variety, performance feedback, performance standards, autonomy, decision-making), they will be motivated (Lussier, 2000; Muchinsky, 1990). While pay and financial security are clearly important, Greenberg and Baron (2000) argue that people are motivated by more than just money. Monetary incentives in the form of pay raises are not guaranteed to motivate employees. In addition, the characteristics (inter alia, knowledge, skills, abilities, locus of control) of the employee also affect the extent to which the individual is motivated to perform the job. Further, the attitudes that the individual has about the self, the work and the organisation play an important role in motivation.

This study postulates that motivation is a critical determinant of job involvement, and subsequently impacts on organisational effectiveness and success. Although significant 
research on the concept of job involvement was conducted from the 1960 s to the late 1980s (Kanungo, 1982; Lodahl \& Kejner, 1965; Rabinowitz \& Hall, 1977) it appears that there is a shortage of contemporary theories and perspectives on this concept, even though interest in this area has increased significantly in recent years (Kirby \& Richard, 2000; Nyambegera, Daniels \& Sparrow, 2001; O'Driscoll \& Randall, 1999). Lodahl and Kejner (1965: 24) define job involvement as the extent to which Individuals identify psychologically with their work, or the importance of the job to their total self-image and self-esteem (Chughtai, 2008; Rotenberry \& Moberg, 2007). Similarly, Kanungo (1982) maintained that job involvement is a cognitive state that reflects the degree of psychological identification that the individual has with the job. According to Muchinsky (1990) job involvement refers to the extent to which individuals are ego-involved in their work. Sherman, Bohlander and Snell (1996: 515) defined job involvement as "the degree of identification employees have with their jobs and the degree of importance they place on their jobs". In other words, job involvement reflects the extent to which individuals are preoccupied with, and immersed or absorbed by, their work activity (Diefendorff, Brown, Kamin \& Lord, 2002; Emery \& Barker, 2007). Job involvement has also been defined as the extent to which individuals tend to exceed the normal expectations associated with their jobs (Moorhead \& Griffin, 1995). Job involvement can thus be viewed as a function of the extent to which the job can satisfy the individual's current needs. In other words, employees' psychological identification with a specific job depends on the extent of their needs and their perceptions of the potential of the job to satisfy them (Emery \& Barker, 2007). Slee-Smith (1973) maintains that job involvement means the kind of co-operation and commitment that results in people finding significance and achievement in their work. Saleh and Hosek (1976) cited in Kanungo (1979) argued that job involvement is a complex concept based on cognition (the extent to which the individual identifies with the job), action (the extent to which the individual actively participates in the job), and feeling (the extent to which the individual considers job performance important to personal self-worth). Lodahl and Kejner (1965) believe that there are four sub-dimensions that are important to job involvement:

- Response to work: Employees have expectations about work, and the extent to which these expectations are met determines the level of job involvement they experience, which, in turn, determines their response to work. Diener et al. (1994) cited in Riipen (1997) argue that employees are more job involved if their needs are fulfilled as a result of the congruence between job expectations and the job itself.

- Expressions of being job involved: The way in which employees express job involvement differs from person to person, and in accordance with the level of job involvement experienced. For example, some employees may express high job involvement by thinking of the job even when they are not at work, while others may become depressed if they fail at something related to the job (Lodahl \& Kejner, 1965).

- Sense of duty towards work: Employees who are highly job involved have a great sense of duty towards work, for example, an employee who is willing to work overtime without pay in order to complete an assigned task.

- Feelings about unfinished work and absenteeism: Employees who are jobinvolved avoid being absent from work and feel guilty about unfinished work (Lodahl \& Kejner, 1965).

Researchers have often debated whether job involvement occurs as a result of value orientations, occurring as an individual difference variable and a personal characteristic that differs from person to person (Dubin, 1956; Lodahl \& Kejner, 1965) or whether it occurs as a function of the situation (Bass, 1965; Vroom, 1962) or as a result of an individual-situation interaction (Lawler \& Hall, 1970; Lodahl \& Kejner, 1965; Muchinsky, 1990). 


\subsection{The relationship between employee motivation and job involvement}

While extensive research has been conducted on employee motivation and job involvement separately and in relation to other variables, there is a paucity of research on the relationship between employee motivation and job involvement, which triggered the need for the current study. The closest connection between employee motivation and job involvement was noted in a study by Tella, Ayeni and Popoola (2007) in which the authors found a correlation between employee motivation and commitment. Tella et al. (2007) based the relationship on Salancik's (1977) definition of commitment as a state of being in which a person becomes bound by his/her actions, and it is these actions that sustain activities and involvement. Likewise, Singh and Kumari (1988) undertook a study on motivation and job involvement in relation to job satisfaction, productivity and absenteeism. Further, Michie, Oughton and Bennion (2002) found that the inter-relationship of sound employee involvement practices with employee ownership has a positive effect on motivation and performance. The conclusion in this study, which focuses on the relationship between employee ownership, motivation and productivity, was that employee involvement increased motivation and commitment, which resulted in increased productivity. Evidently, no studies exist that test the relationship, be it correlational or causal, between employee motivation and job involvement.

In the current study, in testing the relationship between motivation and job involvement, the researchers base their study on Mullins's (1996) definition of motivation to work comprising economic rewards, intrinsic satisfaction and social relationships and Lodahl and Kejner's (1965) sub-dimensions of job involvement, namely, the response to work, expressions of being job involved, the sense of duty towards work, and feelings about unfinished work and absenteeism. It is hypothesised that the level of motivation influences the comparative strength of these four sub-dimensions of job involvement.

The study thus aims to determine:

- the levels of employee motivation and job involvement;

- the nature of the relationship, if any, between employee motivation and job involvement;

- the influence of the biographical variables (age, race, gender, tenure) on employee motivation and job involvement respectively.

2

\section{Research design}

\subsection{Respondents}

The population for the study consisted of a group of 200 permanent and temporary employees from various departments (acquisitions, automated, client operations, collections, corporate, motor, other) at a branch of a financial institution. Since reliability, credibility, precision and competence are critical in the financial sector, job involvement is imperative, and, owing to the routine nature of work in this sector, employee motivation is also crucial. A sample of 145 respondents was drawn using a probability sampling technique called simple random sampling in order to ensure that every employee had a known and equal chance of being selected. According to Sekaran's (2003) population to sample size table, for a population of 200, the minimum size of the corresponding sample should be 132, reflecting the adequacy of a sample size of 145. Questionnaires were distributed to all employees drawn. When selected employees were unavailable or absent, others were drawn using the random method to replace them. The sample is described in terms of age, gender, race and tenure in the organisation, as these variables have the potential to impact on motivation and job involvement. In terms of age, 12.4 per cent of the respondents were from 18-20 years, 33.8 per cent were from 21-25 years, 24.8 per cent were from 26-30 years, 17.3 per cent were from 31-40 years with only 4.8 per cent being from $41-50$ years and only 6.9 per cent being $>50$ years. The majority of the respondents $(58.6 \mathrm{per}$ cent) were therefore from 21-30 years of age. Further, 73.1 per cent of the respondents were females and only 26.9 per cent were males; the representation was proportionate to the gender composition in this organisation. In addition, 55.9 per cent of the respondents were Indian, 
16.5 per cent were Black, 14.5 per cent were Coloureds and 13.1 per cent were White. The largest segment of the employees (52.4 per cent) reflected $1-5$ years of service, followed by 25.5 per cent of the respondents with less than a year of service, then those with 6-10 years (9.7 per cent), $11-15$ years ( 4.8 per cent), $>20$ years ( 4.1 per cent) and lastly, 16-20 years (3.5 per cent); the majority (77.9 per cent) of the respondents therefore had fulfilled $0-5$ years of service.

\subsection{Measuring instruments}

Data were collected using a measuring instrument comprised of three sections. Section A included biographical data relating to age, gender, race, tenure and was measured by using a precoded nominal scale. Section B incorporated the Employee Motivation Questionnaire developed by Fourie (1989). Fourie (1989) used the content and process theories of motivation in developing the motivation questionnaire, the items in which relate to the specific factors or needs that influence the level of motivation experienced by employees. Fourie's Motivation Questionnaire consists of 39 items measured by using a five-point Likert scale, ranging from 'strongly disagree' (1) to 'strongly agree' (5). These are categorised as follows:

- Items 10, 19, 21, 39 tap economic rewards;

- Items 2-4, 6, 7, 9, 11, 13-15, 18, 20, 22-25, 27, 29, 31-37 measure intrinsic satisfaction;

- Items 1, 5, 8, 12, 16, 17, 26, 28, 30, 38 determine social relationships.

In determining the validity of the measuring instrument, factor analysis generated three factors with eigen values $>1$ and a KaiserMeyer-Olkin Measure yielded a value of 0.712 . The Cronbach's Coefficient Alpha of 0.806 indicated that the questionnaire was highly reliable.

Section C was comprised of Lodahl and Kejner's (1965) Job Involvement Scale, consisting of items that encompass specific factors relating to job involvement. Respondents were required to respond to 22 items on the job involvement scale, using a five-point Likert scale ranging from 'strongly disagree' (1) to 'strongly agree' (5) which are categorised as follows:

- Items 10, 14, 16-19 measure response to work;

- Items 2, 3, 6, 7, 9, 11, 15 measure expression of being job-involved;

- Items 1, 4, 8, 12, 20 evaluate the sense of duty towards work;

- Items 5, 13, 21, 22 assess absenteeism and feelings of guilt about unfinished work.

In determining the validity of the instrument, factor analysis generated four factors with eigen values $>1$ and a Kaiser-Meyer-Olkin Measure yielded a value of 0.782 . The alpha coefficient of 0.695 indicated that the questionnaire was reliable.

\subsection{Procedure}

A pilot test of the questionnaire was conducted on 10 subjects as a trial run to detect any weaknesses in the design and instrumentation. The questionnaire was easily understood and no changes were required.

\subsection{Statistical analysis}

Descriptive statistics (frequency analyses, percentages, mean analyses and standard deviations) and inferential statistics (correlation, t-test, ANOVA) were used to analyse the results of the study.

\section{3}

Results

Respondents were required to use the 1-5-point Likert scale to respond to statements measuring sub-dimensions of employee motivation and job involvement, thereby indicating what motivated the respondents to work and what made them feel job-involved. The greater the mean score value, the greater the level of the sub-dimension displayed (Table 1). 


\section{Table 1}

Descriptive statistics of employee motivation and job involvement

\begin{tabular}{|l|c|c|c|}
\hline \multicolumn{1}{|c|}{ Dimension } & Mean & $\begin{array}{c}\text { Standard } \\
\text { deviation }\end{array}$ & Critical range \\
\hline Employee motivation & 3.162 & 0.586 & $3.066-3.258$ \\
\hline Economic rewards & 3.433 & 0.391 & $3.369-3.497$ \\
\hline Intrinsic satisfaction & 3.581 & 0.647 & $3.475-3.687$ \\
\hline Social relationships & & & \\
\hline Job involvement & 2.805 & 0.910 & $2.655-2.954$ \\
\hline Response to work & 3.321 & 0.715 & $3.204-3.439$ \\
\hline Expression of being job involved & 3.583 & 0.701 & $3.468-3.698$ \\
\hline Sense of duty towards work & 2.874 & 0.561 & $2.782-2.966$ \\
\hline $\begin{array}{l}\text { Feelings of guilt regarding unfinished work and } \\
\text { absenteeism }\end{array}$ & & & \\
\hline
\end{tabular}

Table 1 indicates that employees' environments provide the greatest degree of motivation through social relationships $($ Mean $=3.581)$ followed by intrinsic satisfaction (Mean=3.433) and, lastly, through economic rewards $($ Mean $=3.162)$. Although, employees are currently most motivated by social relationships in their workplaces, when the means are compared to a maximum attainable score value of 5 , there is evident room for improvement. The greatest area for improvement is that of economic rewards, followed by intrinsic satisfaction and then social relationships. Frequency analyses were conducted to assess exact areas of improvement in each of the sub-dimensions of employee motivation. In terms of economic rewards, 27 per cent of the subjects agreed, and a further 34 per cent strongly agreed, that when they compared their salaries with those of people in other companies they felt dissatisfied. Further, 25 per cent of the subjects agreed, and a further 26 per cent strongly agreed, that people who started working in the company long after them were financially better off than they were. In terms of intrinsic satisfaction, 26 per cent of the subjects agreed, and a further 8.3 per cent strongly agreed, that the interests of the branch or section enjoyed priority over those of the employees and that career planning was jeopardised in the process. Furthermore, 25 per cent of the subjects agreed, and a further 6.9 per cent strongly agreed, that unnecessary red tape was preventing them from carrying out their daily tasks effectively. In addition, 24 per cent of the subjects agreed, and a further 4.8 per cent strongly agreed, that they did not have enough time to complete their daily tasks. In terms of social relationships, 14 per cent of the subjects agreed, and a further 8.3 per cent strongly agreed, that, if the people in their section disagreed on a matter, it was ignored rather than discussed. The aforementioned signify specific areas for improvement in terms of enhancing employee motivation.

In terms of the sub-dimensions of job involvement, Table 1 indicates that employees displayed only a moderate sense of duty towards work $($ Mean $=3.583)$ followed by being job-involved $($ Mean $=3.321)$ then feelings of guilt about unfinished work and absenteeism $($ Mean $=2.874)$ and, finally, response to work (Mean $=2.805$ ) with the lower means reflecting greater areas for improvement. The mean score values evidently indicate that employees reflected only low to average levels of job involvement. Frequency analyses were therefore conducted to assess exact areas of improvement in each of the sub-dimensions of job involvement. In terms of response to work, 38 per cent of the subjects agreed and a further 14 per cent strongly 
agreed. that as far as they were concerned their work was only a small part of who they were. In addition, 28 per cent of the subjects agreed, and a further 17 per cent strongly agreed, that they had previously been more ambitious about their work than they were now. Further, 26 per cent of the subjects agreed, and a further 19 per cent strongly agreed, that they had other activities that were more important than their work. In terms of feelings of guilt about unfinished work and absenteeism, 17 per cent of the subjects agreed, and a further 7.6 per cent strongly agreed, that they often felt like staying home from work instead of going in. In terms of expressions of being job-involved, 45 per cent of the subjects disagreed, and a further 28 per cent strongly disagreed, that they lived, ate and breathed their jobs. Furthermore, 29 per cent of the subjects disagreed, and a further 15 per cent strongly disagreed, that the most important things that happened to them involved their work. In terms of sense of duty towards work, 14 per cent of the subjects disagreed, and a further 21 per cent strongly disagreed, that they would probably continue working even if they did not need the money. The aforementioned signify specific areas for improvement in terms of enhancing job involvement.

\section{Hypothesis 1}

There are significant intercorrelations among the sub-dimensions of employee motivation (economic rewards, intrinsic satisfaction, social relationships) and the sub-dimensions of job involvement (response to work, expression of being job-involved, sense of duty towards work, feelings of guilt regarding unfinished work and absenteeism) respectively (Table 2).

Table 2

Intercorrelation: sub-dimensions of employee motivation and job involvement

\begin{tabular}{|lc|c|c|c|}
\hline \multicolumn{2}{|c|}{$\begin{array}{c}\text { Sub-dimensions of job } \\
\text { involvement }\end{array}$} & \multicolumn{3}{c|}{ Sub-dimensions of employee motivation } \\
\cline { 3 - 5 } & & Economic rewards & Intrinsic satisfaction & Social relationships \\
\hline Response to work & $r$ & 0.112 & -0.164 & -0.359 \\
& $p$ & 0.178 & $0.049^{*}$ & $0.000^{* *}$ \\
\hline $\begin{array}{llll}\text { Expressions of being job- } \\
\text { involved }\end{array}$ & $\mathrm{r}$ & 0.269 & 0.383 & 0.245 \\
\hline Sense of duty towards work & $\mathrm{r}$ & $0.001^{* *}$ & $0.000^{* *}$ & $0.003^{* *}$ \\
\hline Feelings regarding unfinished & $\mathrm{r}$ & 0.123 & 0.322 & 0.239 \\
work and absenteeism & $\mathrm{p}$ & 0.140 & $0.000^{* *}$ & $0.004^{* *}$ \\
\hline
\end{tabular}

** $\mathrm{p}<0.01 ;{ }^{*} \mathrm{p}<0.05$

Table 2 reflects that:

- Economic rewards significantly correlate with expressions of being job-involved, and feelings of guilt regarding unfinished work and absenteeism respectively, at the 1 per cent level of significance.

- Intrinsic satisfaction correlates significantly but inversely with response to work at the 5 per cent level of significance. This means that the more employees have an affinity with activities other than work, the less was their level of intrinsic satisfaction. In addition, intrinsic satisfaction significantly correlates directly with expressions of being job-involved and the sense of duty towards work respectively, at the 1 per cent level of significance.

- Social relationships significantly but inversely correlate with response to work at the 1 per cent level of significance. In addition, social relationships correlate significantly with expressions of being job-involved and sense 
of duty toward work at the 1 per cent level of significance, respectively. Further, social relationships correlate significantly but inversely with feelings of guilt regarding unfinished work and absenteeism at the 5 per cent level of significance.

The implication is that engaging in strategies that are going to enhance each of the subdimensions of employee motivation will have a spiralling impact and encourage job involvement. However, no significant relationships exist between the remaining sub-dimensions of employee motivation and job-involvement. Hence, hypothesis 1 may be accepted, except for the relationship between economic rewards and response to work and sense of duty towards work respectively and between intrinsic satisfaction and feelings about unfinished work and absenteeism.

\section{Hypothesis 2}

There is a significant difference in the level of employee motivation of employees varying in biographical profiles (age, race, gender, tenure) respectively (Table 3 ).

\section{Table 3}

ANOVA: differences in employee motivation based on biographical profiles

\begin{tabular}{|l|c|c|c|c|c|c|}
\hline $\begin{array}{c}\text { Biographical } \\
\text { variables }\end{array}$ & \multicolumn{3}{|c|}{ Economic rewards } & \multicolumn{2}{c|}{ Intrinsic satisfaction } & \multicolumn{2}{c|}{ Social relationships } \\
\hline & F & p & F & p & F & p \\
\hline Age & 2.293 & $0.049^{*}$ & 2.761 & $0.021^{*}$ & 2.495 & $0.034^{*}$ \\
\hline Race & 1.930 & 0.128 & 0.743 & 0.528 & 0.907 & 0.439 \\
\hline Tenure & 0.729 & 0.558 & 0.398 & 0.850 & 0.650 & 0.661 \\
\hline
\end{tabular}

$* p<0.05$

Table 3 indicates that there is a significant difference in all the sub-dimensions of employee motivation (economic rewards, intrinsic satisfaction, social relationships) between employees varying in age, at the 5 per cent level of significance. In order to determine exactly where these differences lie, Scheffe's post hoc test was conducted (Table 4).

Table 4 indicates that employees in the age group of 41-50 years viewed economic rewards as a satisfying motivator, followed by those in the age group of 26-30 years. Those in the 18-20 years group were the unhappiest with their economic rewards. This may be attributed to expectations not being met or unrealistic expectations on their part.
Table 4 indicates that employees in the age group of 41-50 years, followed by employees in the 18-20 years group, viewed intrinsic satisfaction as a motivator. The employees unhappiest in terms of intrinsic satisfaction were those in the 21-30 years group, whose level of intrinsic satisfaction is negligibly better than those in the 31-40 years group.

Table 4 indicates that employees in the 41-50 years group, followed by those in the over 50 years group and those in the 18-20 years category were satisfied with social relationships at work. Employees in the 26-30 years group were the least motivated by social relationships, with perceptions of social relationships being negligibly better for employees in the 21-25 years group and those in the 31-40 years category. 
Table 4

Scheffe's post hoc test: age

\begin{tabular}{|l|c|c|c|}
\hline $\begin{array}{c}\text { Sub-dimensions of employee } \\
\text { motivation }\end{array}$ & Categories of age & Mean & Standard deviation \\
\hline Economic rewards & $18-20$ years & 2.9722 & 0.47658 \\
& $21-25$ years & 3.1173 & 0.61893 \\
& $26-30$ years & 3.3958 & 0.65839 \\
& $31-40$ years & 3.0000 & 0.44488 \\
& $41-50$ years & 3.4167 & 0.60553 \\
& Over 50 years & 3.1364 & 0.40871 \\
\hline Intrinsic satisfaction & $18-20$ years & 3.6467 & 0.32906 \\
& $21-25$ years & 3.3714 & 0.40669 \\
& $26-30$ years & 3.3722 & 0.38791 \\
& $31-40$ years & 3.3952 & 0.32890 \\
& $41-50$ years & 3.8000 & 0.10431 \\
& Over 50 years & 3.4436 & 0.47915 \\
\hline Social relationships & $18-20$ years & 3.8000 & 0.54880 \\
& $21-25$ years & 3.4959 & 0.67545 \\
& $26-30$ years & 3.4056 & 0.73560 \\
& $31-40$ years & 3.6000 & 0.50744 \\
& $41-50$ years & 4.1667 & 0.45461 \\
& Over 50 years & 3.8091 & 0.46358 \\
\hline
\end{tabular}

Table 3 shows that there are no significant differences in the sub-dimensions of employee motivation (economic rewards, intrinsic satisfaction, social relationships) based on race or tenure.

Table 5

t-Test: economic rewards, intrinsic satisfaction, social relationships and gender

\begin{tabular}{|l|c|c|c|c|c|c|}
\hline \multirow{2}{*}{$\begin{array}{c}\text { Biographical } \\
\text { variables }\end{array}$} & \multicolumn{2}{|c|}{ Economic rewards } & \multicolumn{2}{c|}{ Intrinsic satisfaction } & \multicolumn{2}{c|}{ Social relationships } \\
\cline { 2 - 7 } & $\mathbf{t}$ & $\mathbf{p}$ & $\mathbf{t}$ & $\mathbf{p}$ & $\mathbf{t}$ & $\mathbf{p}$ \\
\hline Gender & 1.213 & 0.229 & 2.613 & $0.011^{*}$ & 2.447 & $0.016^{*}$ \\
\hline
\end{tabular}

${ }^{*} p<0.05$

Table 5 indicates that there is a significant difference in the intrinsic satisfaction and social relationships sub-dimensions of employee motivation between employees varying in gender at the 5 per cent level of significance. In order to determine exactly where these differences lie, Scheffe's post hoc test was conducted (Table 6).

\section{Table 6}

Scheffe's post hoc test: gender

\begin{tabular}{|l|l|c|c|}
\hline Sub-dimensions of employee motivation & \multicolumn{1}{|c|}{ Gender } & Mean & Standard deviation \\
\hline Intrinsic satisfaction & Male & 3.5590 & 0.35022 \\
& Female & 3.3813 & 0.39396 \\
\hline \multirow{2}{*}{ Social relationships } & Male & 3.7718 & 0.51959 \\
& Female & 3.5114 & 0.67984 \\
\hline
\end{tabular}


Table 6 indicates that male employees were more motivated in terms of intrinsic satisfaction and social relationships respectively than were female employees.

Table 5 also indicates that there was no significant difference in economic rewards as a sub-dimension of employee motivation between employees varying in gender. Hence, hypothesis 2 may be accepted only in terms of age.

\section{Hypothesis 3}

There is a significant difference in the level of job involvement between employees varying in biographical profiles (age, race, gender, tenure) respectively (Table 7).

\section{Table 7}

ANOVA: differences in job involvement based on biographical profiles

\begin{tabular}{|l|c|c|c|c|c|c|c|c|}
\hline \multirow{2}{*}{$\begin{array}{c}\text { Biographical } \\
\text { variables }\end{array}$} & \multicolumn{2}{|c|}{ Response to work } & \multicolumn{2}{c|}{$\begin{array}{c}\text { Expression of being } \\
\text { job-involved }\end{array}$} & \multicolumn{2}{c|}{$\begin{array}{c}\text { Sense of duty } \\
\text { towards work }\end{array}$} & \multicolumn{2}{c|}{$\begin{array}{c}\text { Absenteeism and } \\
\text { feelings of guilt about } \\
\text { unfinished work }\end{array}$} \\
\cline { 2 - 10 } & $\mathbf{F}$ & $\mathbf{p}$ & $\mathbf{F}$ & $\mathbf{p}$ & $\mathbf{F}$ & $\mathbf{p}$ & $\mathbf{F}$ & $\mathbf{p}$ \\
\hline Age & 1.554 & 0.177 & 3.250 & $0.008^{* *}$ & 1.450 & 0.210 & 0.601 & 0.699 \\
\hline Race & 0.487 & 0.692 & 1.396 & 0.247 & 0.599 & 0.617 & 0.437 & 0.727 \\
\hline Tenure & 0.946 & 0.453 & 0.654 & 0.659 & 1.433 & 0.216 & 1.084 & 0.372 \\
\hline
\end{tabular}

$* \mathrm{p}<0.01$

Table 7 indicates that there was a significant difference in expressions of being job-involved among employees varying in age at the 1 per cent level of significance. In order to determine where these differences lie, Scheffe's post hoc test was conducted (Table 8).

\section{Table 8}

Scheffe's post hoc test: age

\begin{tabular}{|l|c|c|c|}
\hline \multicolumn{1}{|c|}{$\begin{array}{c}\text { Sub-dimensions of job } \\
\text { involvement }\end{array}$} & Categories of age & Mean & Standard deviation \\
\hline $\begin{array}{l}\text { Expression of being job } \\
\text { involved }\end{array}$ & $18-20$ years & 3.5476 & 0.61445 \\
& $21-25$ years & 3.1283 & 0.70785 \\
& $26-30$ years & 3.3294 & 0.66290 \\
& $31-40$ years & 3.2686 & 0.77407 \\
& $41-50$ years & 4.2143 & 0.67461 \\
& Over 50 years & 3.4156 & 0.58013 \\
\hline
\end{tabular}

Table 8 reflects that employees between $41-50$ years of age expressed the highest level of job involvement, followed by those who were 18-20 years of age. Employees from 21-25 years of age expressed the lowest level of job involvement.

Table 7 also shows that no significant differences were reflected in the other sub- dimensions of job involvement (response to work, sense of duty towards work, feelings of guilt about unfinished work and absenteeism) among employees varying in age. Further, none of the sub-dimensions of job involvement were influenced by race and tenure. 
Table 9

t-test: difference in job involvement based on gender

\begin{tabular}{|l|c|c|c|c|c|c|c|c|}
\hline $\begin{array}{c}\text { Biographical } \\
\text { variables }\end{array}$ & \multicolumn{2}{|c|}{ Response to work } & \multicolumn{2}{|c|}{$\begin{array}{c}\text { Expression of } \\
\text { being job-involved }\end{array}$} & \multicolumn{2}{|c|}{$\begin{array}{c}\text { Sense of duty } \\
\text { towards work }\end{array}$} & \multicolumn{2}{|c|}{$\begin{array}{c}\text { Absenteeism and } \\
\text { feelings of guilt about } \\
\text { unfinished work }\end{array}$} \\
\cline { 2 - 9 } & $\mathbf{t}$ & $\mathbf{p}$ & $\mathbf{t}$ & $\mathbf{p}$ & $\mathbf{t}$ & $\mathbf{p}$ & $\mathbf{t}$ & $\mathbf{p}$ \\
\hline Gender & -1.771 & 0.079 & 0.012 & 0.991 & 0.119 & 0.906 & -1.031 & 0.304 \\
\hline
\end{tabular}

Table 9 reflects that there was no significant difference in the sub-dimensions of job involvement between male and female employees. Hence, hypothesis 3 may not be accepted.

\section{4 \\ Discussion}

\subsection{Interpretation}

\section{Employee motivation}

Pay and benefits are often a stimulating force and are key drivers of motivation (Anonymous, 2007; Stanley, 2008). However, in terms of economic rewards, employees in the study were not motivated purely by what they received for their efforts but by comparing with what others received. Benson and Dundis (2003) found that individuals who believe that they are not being paid a fair remuneration spend too much time contemplating this perceived inequity, to the detriment of other work concerns. Adams, cited in Lussier (2000) believes that when employees compare themselves with others, they reach one of three possible conclusions. They believe that they are under-rewarded, over-rewarded or equitably rewarded; this conclusion determines whether or not employees are experiencing motivation. Paying employees a comparable salary has been found to result in their sense of being valued, which, in turn, increases motivation (Internet 1, 2006). It is especially important to pay attention to the salaries of long-service employees, as it is often the case in contemporary organisations that younger, often better educated, employees are paid better salaries upon entering the organisation than those of their long-term counterparts, and this could lead to lack of motivation among long- service employees. However, money alone is not the best way of motivating employees, and this implies that the perceived inequities do not have a significant effect on motivation in the long term (Nelson, 1996; Skabelund, 2008; Snyder, 2007). Matthews (2007) suggests vouchers - for anything from childcare to balloon rides - as a desirable alternative, especially when they are presented publicly by the boss.

In terms of intrinsic satisfaction, Greenberg and Baron (2000) argue that people are motivated by more than just money. In this study, about one third of the respondents ( 31.9 per cent) emphasised that unnecessary red tape was preventing them from carrying out their daily tasks effectively. An effective way of increasing motivation levels (Nelson, 1996) is to remove red tape and involve employees in decision-making, especially decisions that affect them, which gives them a sense of ownership in their work and their work environment. The findings by DeHart-Davis and Pandey (2005) prove that red tape and other forms of bureaucratic control have a negative impact on the psychological attachment of employees in the workplace. Other strong motivators could be instrumental support in completing tasks (Van Yperen, 2002), proper design of job tasks (Internet 2, 1996), personally-designed travel incentives (Lallande, 2007) and recognising and celebrating employee successes (Snyder, 2007). In addition, some people want to belong to a company with a top-class reputation, one that has a culture and a positive workplace to match (Marketing Week, 2007; Snyder, 2007). Individuals with a high need for achievement prefer to develop the skills, expertise and competencies required to perform well, so career planning (Schultz et al., 2003) and training and promotional opportunities for employees (Stanley, 2008) may be another important motivational tool. 
The results of this study emphasise the importance of social relationships. In order to be motivated, employees must have a feeling of social comfort within the organisation and must experience pleasant working conditions with co-workers and others in the hierarchy in both formal and informal settings, thereby emphasising the need for social acumen (Charan, 2008). The need for affiliation becomes an increasingly important source of motivation in highly demanding jobs, as the emotional support and positive reinforcement offered by others seems to ease the stress associated with the job demands and creates a gratifying workplace (Nicholson, 2003; Stanley, 2008; Van Yperen, 2002). Lloyd (2006) believes that if the manager discovers what each person's internal motivators and goals are and then ties these in with the work at hand, motivation will soar. Thiedke (2004) maintains that a motivating factor for employees is that of being able to discuss things when they go wrong.

\section{Job involvement}

The results of the study reflect that it is the individual that decides the response to work, that is, whether one believes that work is one's most important activity, or whether work forms only a small part of who one is. Expressions of being job involved determine the extent to which different employees live, eat and breathe the job. Rabinowitz and Hall, cited in Riipinen (1997) argue that the variance in levels of such job-involvement is partially caused by the congruence between the individual's needs and the characteristics of the job or, how well the job meets the individual's needs. Researchers have found that expressions of being job-involved are directly related to the wellbeing of the employee (Wiener, Muczyk \& Gable, 1987). The findings of this study reflect a changing sense of duty towards work, with a large segment of employees (35 per cent) indicating that they would not continue to work if they did not need the money. Respondents also indicated tendencies to be absent and late. According to Diefendorrf et al. (2002) a highly job-involved individual feels compelled to stay late at work, attend nonmandatory meetings, and forego extra breaks from work. However, Wegge, Schmidt, Parkes \& van Dick (2007) maintain that job involvement affects absenteeism more if job satisfaction is low, as this reflects a scenario with weak constraints. Stanley (2008) believes that deep down there is a mysterious, dynamic, emotional phenomenon called devotion, which acts as a motivational force to dedicate employees to their jobs to such an extent that their job has the potential to define them.

\section{Relationship between employee motivation and job involvement}

The results of the study indicate a significant and direct relationship between economic rewards and expressions of being job-involved and feelings of guilt about unfinished work and absenteeism, thereby stressing the importance of pay, benefits, material goods and security in enhancing job involvement. Furthermore, there is a significant and direct relationship between intrinsic satisfaction as a motivator and expressions of being job-involved and having a sense of duty towards work respectively. Hence, a positive work/life balance may contribute to greater employee motivation (Duff, 2006) and the consequent, enhanced job involvement. However, there is a significant though inverse relationship between intrinsic satisfaction and response to work, implying that, the greater the level of intrinsic satisfaction, the lower the response to work. There is also a significant but inverse relationship between social relationships and response to work and feelings of guilt about unfinished work and absenteeism. The implication is that social relationships may be a motivator, but an excess in that area could potentially reduce both the response to work and feelings of guilt about unfinished work and absenteeism. In other words, it could create a 'more play, less work' attitude.

\section{Biographical correlates}

The results reflect that age impacts on all the sub-dimensions of employee motivation (economic rewards, intrinsic satisfaction, social relationships) and was supported by similar findings in the 2006 SEEK Intelligence Survey (Internet 3, 2006). Further, Madsen et al. (2005) found signification correlations between social relationships and gender. In this study, male 
and female employees displayed significant differences in the intrinsic satisfaction and social relationships sub-dimensions of employee motivation. The difference in motivation between males and females may be attributed to how each gender perceives work. Men place a higher value than women do on instrumental values, such as basic salary and bonuses, whereas women place more importance than men do on inter-personal relationships at the workplace, respectful treatment by the employer, and the possibility of reconciling work and family life (Internet 4, 1996). In this study, employees varying in age display significant differences in expressions of being job-involved, a result that was supported by findings by other researchers (Lorence, 1987; Morrow \& McElroy, 1987; Remondet \& Hansson, 1991; Riipinen, 1997; Shore, Thornton III \& Shore, 1990).

\subsection{Conclusions}

The majority of the sub-dimensions of employee motivation correlate significantly with those of job involvement ( 9 out of 12 pairs of dimensions), thereby validating the hypothesis that there is a significant relationship between employee motivation and job involvement. The implication is that managers could influence the sub-dimensions of employee motivation in attempts to enhance job involvement. This may be a strategic maneuver, since Moynihan and Pandey (2007) caution that managers have the least influence over job involvement.

\subsection{Recommendations}

In this study, a significant number of respondents indicated that they were not motivated, owing to a lack of satisfaction when they compared their salaries with those of their counterparts in other companies. Also, the fact that a number of respondents in this study indicated that people who started working in the company long after they did were financially better off than they were, results in a lack of motivation. Thus, if increasing employee motivation is a priority, organizations should strive to offer employees equitable, market-related, yet competitive salary packages. Length of service should not be the only criterion for determining bonuses and salary increases. Instead, organisations should consider offering long-term employees monetary and other incentives (such as personally-designed travel incentives, vouchers) as a means of enhancing employee motivation.

In terms of this study, about one third of the respondents believed that unnecessary red tape was preventing them from carrying out their daily tasks effectively and that they did not have enough time to complete their daily tasks. Organisations should review their hierarchies and structure, as well as implement strategies like delegation and empowerment possibly through participative decision-making, in an effort to eliminate unnecessary red tape. In order to increase employee motivation, organisations should invest in proper job-design strategies, such as giving employees sufficient time to complete tasks. When designing jobs, cognizance should be given to clear outputs and standards, proper goal-setting and setting achievable deadlines.

Respondents in the study implied that the interests of the branch/section enjoyed priority over those of the employees, and that career planning was jeopardised in the process. Organisations that wanted to enhance employee motivation should ensure that career planning and learning and development initiatives (skills development, management development, coaching and mentoring) were in place, and that employees had access to relevant and sufficient information regarding their career opportunities.

Lack of motivation among a significant number of respondents could be attributed to the fact that they felt that they were being kept in one section for too long, which could jeopardise their careers. Employee motivation could be enhanced through the implementation of job rotation. This would ensure that employees were able to move through different departments, thereby gaining the knowledge, skills and abilities they needed for multitasking and progressing in their careers.

The study reveals that a significant number of the subjects believed that if the people in their section disagreed on something the matter was ignored rather than discussed. It is thus clearly important to encourage organisational 
communication, perhaps through daily or weekly departmental meetings to be attended by both management and staff, during which employees could air their opinions and concerns and receive feedback from management.

A considerable number of subjects agreed that they had other activities that were more important than their work, that their work was only a small part of who they were, and that they had previously been more ambitious about their work than they were when they responded to the questionnaire. In order to enhance employees' feelings of job involvement, organisations should strive to create jobs that are meaningful, challenging and interesting, and ensure that excellent performance is recognised and rewarded.

The recommendations based on the results of the study are represented in Figure 1.

\section{Figure 1}

Recommendations based on the results of the study

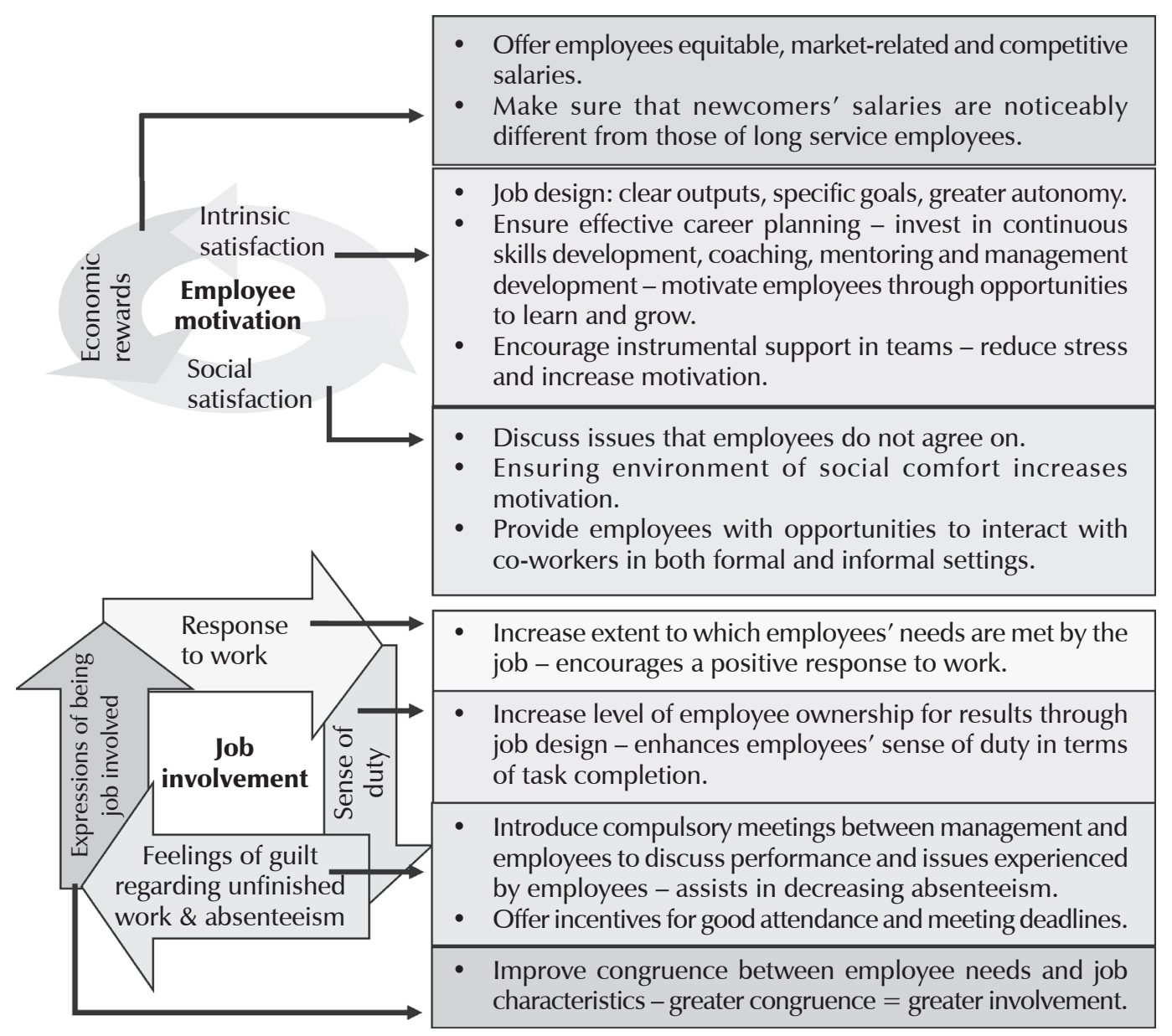

\subsection{Suggestions for further research}

Having obtained greater insight into the relationship between employee motivation and job involvement, greater clarity on the relationship between job involvement and organisational commitment is necessary owing to the contradictory results obtained in this area (Blau \& Boal, 1989; Dubinsky \& Hartley, 1986; Huselid \& Day, 1991; Sjoberg \& Sverke, 2000). 


\section{References}

ANONYMOUS. 2007. Pay and benefits often a key motivation driver, Benefits \& Compensation International, 37(5): 40.

BASS, B.M. 1965. Organizational psychology, Allyn \& Bacon: Boston.

BENSON, S.G. \& DUNDIS, S.P. 2003. Understanding and motivating health care employees: integrating Maslow's hierarchy of needs, training and technology, Journal of Nursing Management, 11(5) http://search. epnet. htm/login.aspx?direct $=$ true $\&$ AuthType $=$ coo kie,ip,url,uid \&db=buh\&an=10651067 (Accessed 30 January 2007).

BLAU, G. \& BOAL, K. 1989. Using job involvment and organizational commitment interactively to predict turnover, Journal of Management, 15(1) http://search. epnet.com/login.aspx ?direct $=$ true $\&$ AuthType $=$ co okie,ip,url,uid $\& \mathrm{db}=$ buh $\&$ an = number $($ Accessed 5 September 2006).

CHARAN, R. 2008. People acumen, Leadership Excellence, 25(3) ABI/INFORM Global: 15.

CHUGHTAI, A.A. 2008. Impact of job involvement on in-role job performance and organizational citizenship behaviour, Journal of Behavioural and Applied Management, 9(2): 169-184.

DEHART-DAVIS, L. \& PANDEY, S. 2005. Red tape and public employees: does perceived rule dysfunction alienate managers? Journal of Public Administration Research and Theory, 15(1): 133-148.

DIEFENDORFF, J.M., BROWN, D.J., KAMIN, A.M. \& LORD, R.G. 2002. Examining the roles of job involvement and work centrality in predicting organizational citizenship behaviours and job performance, Journal of Organizational Behaviour, 23: 93-108, http://search.epnet. com/login.aspx? direct $=$ true $\&$ AuthType $=$ cookie, ip, url, uid $\& \mathrm{db}=$ buh $\&$ an=6292712 (Accessed 5 September 2006).

DUBIN, R. 1956. Industrial workers' worlds: a study of the central life interests of industrial workers, Social Problems, 3: 131-142.

DUBINSKY, A.J. \& HARTLEY, S.W. 1986. A pathanalytic study of a model of salesperson performance, Journal of the Academy of Marketing Science, 4: 36-46. DUFF, A. 2006. Advice squad, Director, 59(12) ABI/ INFORM Global: 25.

EMERY, C.R. \& BARKER, K.J. 2007. Effect of commitment, job involvement and teams on customer satisfaction and profit, Team Performance Management, 13(3/4): 90-101.

FOURIE, L.A. 1989. Die motivering van blanke klerke by ' $\mathrm{n}$ finansiele instelling Potchefstroomse Universiteit vir CHO, Potchefstroom: M.Com. Skripsie.
GERBER, P.D., NEL, P.S. \& VAN DYK, P.S. 1998. Human resource management $\left(4^{\text {th }} \mathrm{ed}\right.$.) Halfway House: International Thomson Publishing.

GREENBERG, J. \& BARON, R.A. 2000. Behaviour in organizations: understanding and managing the human side of work ( $7^{\text {th }}$ ed.) Prentice Hall: New Jersey. HERZBERG, F. 1968. One more time: How do you motivate employees?, Harvard Business Review, 81(1): 87-96.

HUSELID, M.A. \& DAY, N.A. 1991. Organizational commitment, job involvement and turnover: A substantive and methodological analysis, Journal of Applied Psychology, 76: 380-391.

INTERNET 1. 2006 Keeping employees motivated, http://search.epnet. com/login.aspx? direct $=$ true \&A uthType $=$ cookie, ip ,url,uid $\& \mathrm{db}=$ buh $\&$ an $=2146731$ (Accessed 30 January 2007).

INTERNET 2. 1996. Motivating workers, IIE Solution, 28(8) http:// search.epnet.com/login.aspx?d irect $=$ true $\&$ AuthType $=$ cookie, ip, url, $u$ id $\& \mathrm{db}=\mathrm{aph} \&$ an $=9608231770$ (Accessed 3 July 2004).

INTERNET 3. 2006. SEEK Intelligence 2006

Employee satisfaction and motivation, http://www.seek. com.au (Accessed 1 November 2007).

INTERNET 4. 1996. Motivating workers, http://search. epnet.com/login.aspx ? direct $=$ true $\&$ AuthType $=$ cook ie, ip, url,uid \&db=buh\&an=9608231770 (Accessed 30 January 2007).

KANUNGO, R.N. 1979. The concepts of alienation and involvement revisited, Psychological Bulletin, 86(1): 119-138.

KANUNGO, R.N. 1982. Measurement of job and work involvement, Journal of Applied Psychology, 67(3): 341-349.

KIRBY, S.L. \& RICHARD, O.C. 2000. Impact of marketing: work-place diversity on employee job involvement and organizational commitment, The Journal of Social Psychology, 140(3) http://search.epnet. $\underline{\text { com} / \operatorname{login} . \text { aspx }}$ ? direct $=$ true $\&$ AuthType $=$ cookie, ip, $\mathrm{u}$ rl,uid $\& \mathrm{db}=$ buh $\& a n=3308135$ (Accessed 5 September 2006).

LALLANDE, A. 2007. How to design travel incentives, HRMagazine, December: 63-65.

LAWLER, E.E. III \& HALL, D.T. 1970. Relationship of job characteristics to job involvement, satisfaction and intrinsic motivation, Journal of Applied Psychology, 54: 305-312.

LLOYD, J. 2006. Just whose job is it to motivate employees? Receivables Report for America's Health Care Financial Managers, 21(8): 9-11, http://search. epnet.com/login.aspx ?direct $=$ true $\&$ AuthType $=$ cookie, ip,url,uid $\& \mathrm{db}=$ buh \&an $=21673600$ (Accessed 1 August 2006). 
LODAHL, T.M. \& KEJNER, M. 1965. The definition and measurement of job involvement, Journal of Applied Psychology, 49(1): 24-33.

LORENCE, J. 1987. A test of 'gender' and 'job' models of sex differences in job involvement, Social Forces, 66(1): 121-142.

LUSSIER, R.N. 2000. Management fundamentals: concepts applications skills development South-Western College Publishing: USA.

MADSEN, S.R., MILLER, D. \& JOHN, C.R. 2005.

Readiness for organizational change: do organizational commitment and social relationships in the workplace make a difference? Human Resource Development Quarterly, 16(2): 213-233.

MARKETING WEEK 2007. Employee motivation: all the fun of the share, June 28, 2007: 33.

MATTHEWS, V. 2007. What's in your wallet?

Personnel Today, 17 April 2007 ABI/INFORM Global: 26-28.

MICHIE, J., OUGHTON, C. \& BENNION, Y. 2002. Employee ownership, motivation and productivity, $A$ research report for employees direct from Birkbeck and The Work Foundation. London: Birkbeck University of London.

MOORHEAD, G. \& GRIFFIN, R.W. 1995.

Organizational behaviour: managing people and

organizations Houghton: Mifflin Company: USA.

MORROW, P.C. \& McELROY, J.C. 1987. Work

commitment and job satisfaction over three career

stages, Journal of Vocational Behaviour, 30(3): 330-346. MOYNIHAN, D.P. \& PANDEY, S.K. 2007. Finding workable levers over work motivation: comparing job satisfaction, job involvement, and organizational commitment, Administration \& Society, 39(7): 803-832. MUCHINSKY, P.M. 1990. Psychology applied to work: an introduction to industrial and organizational psychology ( $3^{\text {rd }}$ ed.) Brooks/Cole Publishing Company: USA.

MULLINS, L.J. 1996. Management and organizational behaviour (4 ${ }^{\text {th }}$ ed.) Pitman Publishing: Great Britain.

NELSON, B. 1996. Dump the cash, load on the praise, Personnel Journal, 75: 65-70.

NELSON, D.L. \& QUICK, J.C. 2002. Understanding organizational behaviour: a multimedia approach, South-Western, Thomson Learning: USA.

NICHOLSON, N. 2003. How to motivate your problem people, Harvard Business Review, 81(1): 57-65. NYAMBEGERA, S.M.; DANIELS, K. \& SPARROW, P. 2001. Why fit doesn't always matter: the impact of HRM and cultural fit on job involvement of Kenyan employees, Applied Psychology: An International Review, 50(1) http://search.epnet.com/login.aspx?dir ect $=$ true $\&$ AuthType $=$ cookie, ip, url,uid $\& \mathrm{db}=$ buh $\&$ an $=4335518$ (Accessed 5 September 2006).
ODENDAAL, A. \& ROODT, G. 2003. Basic motivation concepts, in S.P. Robbins, A. Odendaal \& G. Roodt. 2003. Organizational behaviour: global and Southern African perspectives, Pearson Education: South Africa: 130-149.

O’DRISCOLL, M.P. \& RANDALL, D.M. 1999. Perceived organizational support, satisfaction with rewards and employee job involvement and organizational commitment, Applied Psychology: An International Review, 48(2) http:// search.epnet. com/login .aspx .direct $=$ true $\&$ AuthType $=$ cookie, ip, url,uid $\&$ db $=$ buh $\& a n=4423124$ (Accessed 5 September 2006).

PRETORIUS, W. 2004. Organizational factors influencing the transformational process of a financial institution, Unpublished thesis. University of Pretoria: South Africa.

RABINOWITZ, S. \& HALL, D.T. 1977.

Organizational research on job involvement,

Psychological Bulletin, 84(2): 265-288.

REMONDET, J. \& HANSSON, R. 1991. Job-related threats to control among older employees, Journal of Social Issues, 47: 129-141.

RIIPINEN, M. 1997. The relationship between job involvement and well-being . Journal of Psychology, 131(1)

http://search.epnet.com/login.aspx?direct $=$ true \&Aut hType $=$ cookie, ip, url,uid $\& d b=$ buh $\&$ an $=9703192190$ (Accessed 5 September 2006).

ROTENBERRY, P.F. \& MOBERG, P.J. 2007.

Assessing the impact of job involvement on performance, Management Research News, 30(3): 203-215.

SCHULTZ, H., BAGRAIM, J., POTGIETER, T., VIEDGE, C. \& WERNER, A. 2003. Organizational behaviour: a contemporary South African perspective', Van Schaik Publishers: Pretoria.

SEKARAN, U. 2003. Research methods for business: $a$ skill building approach ( $4^{\text {th }}$ ed.) John Wiley and Sons: Southern Illinois.

SHERMAN, A., BOHLANDER, G. \& SNELL, S. 1996. Managing human resources, South-Western College Publishing: Cincinnati, Ohio.

SHORE, T.; THORNTON III, G. \& SHORE, L. 1990. Distinctiveness of three work attitudes: job involvement, organizational commitment, and career salience, Psychological Reports, 167: 851-858.

SINGH, A. \& KUMARI, P. 1988 A study of individual need strength, motivation and job involvement in relation to job satisfaction, productivity and absenteeism, Managerial Psychology, 1: 24-42.

SJOBERG, A. \& SVERKE, M. 2000. The interactive effect of job involvement and organizational commitment on job turnover revisited: a note on the 
mediating role of turnover intention, Scandinavian

Journal of Psychology, 41(3)

http://search. epnet.com/login.aspx?direct = true\&Auth

Type $=$ cookie,ip, rl,uid $\& d b=$ buh $\& a n=4336($ Accessed 5 September 2006).

SKABELUND, J. 2008. I just work here, American Fitness, 26(3): 42.

SLEE-SMITH, P.I. 1973. Job involvement and communication, Business Books Limited: London. SNYDER, G. 2007. The motivated staff: It's not an impossible dream, DVM, June: 44-45.

STANLEY, T.L. 2008. A motivated workplace is a marvelous sight, SuperVision, 69(3) ABI/INFORM Global: 5-8.

TELLA, A., AYENI, C.O. \& POPOOLA, S.O. 2007.

Work motivation, job satisfaction, and organizational commitment of library personnel in academic and research libraries in Oyo State, Nigeria, Library Philosophy and Practice, April.

THIEDKE, C.C. 2004. What motivates staff? Family Practice Management, 11(10) http://search.epnet.com/login.aspx?direct=true \&Auth Type $=$ cookie, ip, url,uid $\& d b=$ buh $\&$ an $=15232696$ (Accessed 30 January 2007).

VAN YPEREN, N.W. 2002. Employees facing high job demands: how to keep them fit, satisfied, and intrinsically motivated? Academy of Management Proceedings, 2002,

http://search.epnet.com/login.aspx?direct $=$ true \&Auth Type $=$ cookie, ,ip, url,uid $\& \mathrm{db}=$ buh $\&$ an $=7517550$

(Accessed 17 July 2004).

VROOM, V.H. 1962. Ego-involvement, job satisfaction, and job performance, Personnel Psychology, 15: 159-177.

WEGGE, J., SCHMIDT, K-H., PARKES, C. \& VAN

DICK, R. 2007. Taking a sickie: job satisfaction and job involvement as interactive predictors of absenteeism in a public organization, Journal of Occupational and Organizational Psychology, 80(1): 77.

WIENER, Y., MUCZYK, J.P. \& GABLE, M. 1987.

Relationships between work commitment and experience of personal well-being, Psychological Reports, 60: 450-466. 